\title{
Sowing time affecting the development of common bean cultivars in Lichinga, Province of Niassa, Mozambique
}

\author{
Maria da Conceição Santana Carvalho ${ }^{1}$, Adriano Stephan Nascente ${ }^{1 *}$, Gilvan Ferreira Barbosa ${ }^{2}$, \\ Celso Américo Pedro Mutadiua ${ }^{3}$, José Eloir Denardin ${ }^{4}$
}

$10.1590 / 0034-737 X 201764050011$

\begin{abstract}
The demonstration of yield potential of crops depends on genetic factors, favorable conditions of environment, and management. The sowing time can significantly affect the common bean grain yield. The aim of this research was to study the behavior of Brazilian cultivars and sowing times on the yield components and grain yield of common bean grown in the environmental conditions of Lichinga, Province of Niassa, Mozambique. The field trial was performed for two growing seasons, using the experimental as a randomized block in factorial $5 \times 3 \times 2$, with four replications. The treatments consisted of the combination of five common bean cultivars (BRS Pontal, BRS Agreste, Perola, and BRS Requinte, developed by Brazilian Agricultural Research Corporation (Embrapa), and a local variety, Encarnada) with three sowing dates (beginning of the rainy season, and 15 and 30 days after), during two growing seasons. The Brazilian cultivar of common beans BRS Pontal was the most productive in all sowing times, followed by BRS Agreste, which was not the most productive only in the second sowing time of 2013/2014 growing season. The cultivar Encarnada, from Mozambique, was the less productive cultivar in all sowing times and in all growing seasons. The best sowing time for common bean cultivars is in the beginning of the rainy season. The use of technologies such as use of seeds of new cultivars, proper sowing time, fertilization, and control of weeds allow significant increase of common bean grain yield in Lichinga, Mozambique.
\end{abstract}

Keywords: Phaseolus vulgaris L.; genotype-environment interaction; yield; food production.

\section{RESUMO}

\section{Época de semeadura afetando o desenvolvimento de cultivares de feijão em Lichinga, província de Niassa, Moçambique}

A manifestação do potencial produtivo das culturas depende de fatores genéticos e de condições favoráveis de ambiente e de manejo. A época de semeadura pode afetar significativamente a produtividade de grãos do feijão comum. O objetivo do trabalho foi de estudar o comportamento de cultivares brasileiras e épocas de semeadura nos componentes de produção e produtividade de grãos do feijão comum cultivado nas condições ambientais de Lichinga, Província de Niassa, Moçambique. O experimento de campo foi conduzido em duas safras agrícolas, utilizando-se o delineamento experimental de blocos casualisados em esquema fatorial $5 \times 3 \times 2$, com quatro repetições. Os tratamentos constaram da combinação de cinco cultivares de feijão comum (BRS Pontal, BRS Agreste, BRS Perola e BRS Requinte, desenvolvidas pela Embrapa e uma variedade local, Encarnada) com três épocas de semeadura (início do período chuvoso, 15 e 30 dias após) e duas safras agrícolas. A cultivar brasileira de feijão comum BRS Pontal foi a mais produtiva em todas as épocas

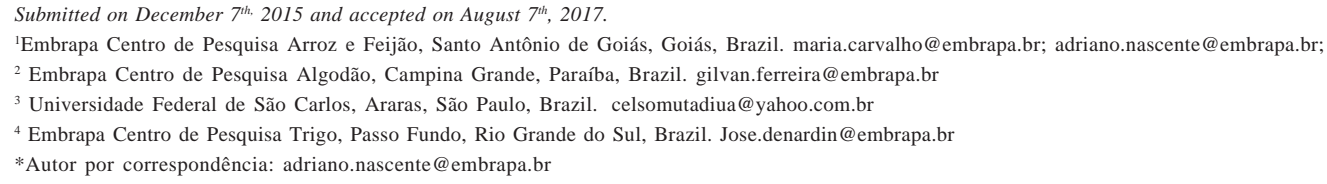

Rev. Ceres, Viçosa, v. 64, n.5, p. 532-539, set/out, 2017 
de semeadura, seguidas da BRS Agreste, que não foi a mais produtiva, somente na segunda época de semeadura da safra 2013/2014. A cultivar Encarnada de Moçambique foi a cultivar menos produtiva em todas as épocas de semeadura e em todas as estações de crescimento. A melhor época de semeadura para as cultivares de feijoeiro-comum é no início do período chuvoso. O uso de tecnologias como o uso de sementes de novas cultivares, época de semeadura adequada, adubação e controle de plantas daninhas permitem aumentar significativamente a produção de grãos do feijoeirocomum em Lichinga, Moçambique.

Palavras-chave: Phaseolus vulgaris L.; interação genótipo-ambiente; produtividade.

\section{INTRODUCTION}

The common bean (Phaseolus vulgaris L.) is one of the most important legumes for human consumption because of its high nutritional value and protein content (Shinano et al., 1993; Fageria, 2002). In many areas, common bean is the second most important source of calories after maize. Over 200 million people in sub-Saharan Africa depend on this crop as a primary staple, which is cultivated largely by women that use local varieties of common bean with limited use of technology (CGIAR, 2011). Furthermore, millions of small-scale farmers in Latin America and Africa rely on the production and sale of beans as an important source of household income (CGIAR, 2015).

However, despite of its importance, low use of modern technology is still observed, resulting in low grain yield worldwide of only $785 \mathrm{~kg} \mathrm{ha}^{-1}$ (FAOSTAT, 2015). In Brazil, for example, by the use of modern technologies (seeds of new varieties, proper row spacing, fertilization, pest, and control of diseases and weeds), there are producers reaching grain yield of $3.500 \mathrm{~kg} \mathrm{ha}^{-1}$ (Nascente et al., 2012; Nascente \& Cobucci, 2015). In Africa, in 2013, there was a production of 4.97 million $\mathrm{Mg}$ and a grain yield of $657 \mathrm{~kg}$ $\mathrm{ha}^{-1}$; in Mozambique, in the same year, 190,000 Mg of common bean grain was produced with a grain yield of only $345 \mathrm{~kg} \mathrm{ha}^{-1}$ (FAOSTAT, 2015). This low grain yield is a problem, once the demand for dry beans in Africa is large and there is a growing expectation for the next decades (Kumar et al., 2009; Birthal et al., 2010; Parthasarathy Rao et al., 2010).

The development of new cultivars of common bean by breeding programs is one of the main actions aimed at increasing grain yield and food security in most countries, such as Mozambique. Improved cultivars provide increased grain yield, disease resistance, and improved seed quality. For success in cultivar recommendations, it is necessary that these materials be evaluated in various locations and times to provide information about cultivar adaptation for each region, since the performance of plant cultivars can be affected by variations in the environment where they are grown (Redden et al., 2000; Dalla Corte et al., 2002).
However, in Mozambique, there are virtually no breeding programs with common bean. Thus, one alternative would be the evaluation of cultivars developed in other countries, such as Brazil, in the environmental conditions of Mozambique to identify the most adapted material to local conditions.

The recommended sowing periods for rainfed agriculture are those with less possibility of climate risks. High air temperatures are harmful to the production of beans, especially during critical phases such as flowering (R6), pod formation (R7), and grain filling (R8). Areas with average temperature values between 15 and $29.5{ }^{\circ} \mathrm{C}$ are considered suitable for common bean cultivation (Gonçalves et al., 1997; Maluf et al., 2001; Fancelli \& Dourado Neto, 2007).

As for precipitation, the common bean is considered a crop of low tolerance to water stress and requires at least $300 \mathrm{~mm}$ of rainfall during the cycle and in the critical periods during the flowering and the initial stage of pod formation (Cunha et al., 2013), water consumption can reach $5 \mathrm{~mm}$ per day (Fancelli \& Dourado Neto, 2007). The risks caused to common bean grain production due to reduced availability of water can be minimized when the crop is sowed in periods with high probability of rainfall during periods of increased demand for crop.

The use of appropriate technologies, such as row spacing, proper sowing time, fertilization, seeds of new varieties, and weed control will provide significant increases in grain yield of common bean development in Mozambique. The objective was to study the performance of Brazilian cultivars and sowing times in the components of production and, common bean grain yield in the environmental conditions of Lichinga, Niassa Province, Mozambique.

\section{MATERIAL AND METHODS}

The study was conducted in the experimental field of the Centro Zonal de Investigação Noroeste (CZINw) of the Instituto de Investigação Agrícola de Moçambique (IIAM), in the district of Lichinga, province of Niassa, 
located in northern Mozambique (13'23'48" S and 35'13'43" E). The altitude of the region varies from 1000 to $1300 \mathrm{~m}$. According to Köppen classification, the climate of the region is humid temperate $(\mathrm{Cwb})$, with two well distinguished seasons (temperate, rainy summers and dry, cold winters). The region presents average annual rainfall varying between 1000 and $1500 \mathrm{~mm}$, while the average annual temperature is between 20 and $23{ }^{\circ} \mathrm{C}$ (Ministério da Administração Estatal, 2005; Mbanze et al., 2015). Rainfall and temperature were monitored during the trial period (Figure 1).
The soil is classified as clay loam Ferralsols (FAO, 1998). Before the deployment of the trials, in September 2012 and October 2013, clay and chemical analyzes were performed at a depth of $0-0.20 \mathrm{~m}$ to characterize the experimental area (Table 1). In both seasons, we used the same place and the second year the area was $500 \mathrm{~m}$ apart from the first one. The chemical analyzes were performed according to the methodology proposed by Claessen (1997). The soil pH was determined in water suspension (1:2.5 soil/solution). Exchangeable $\mathrm{Ca}, \mathrm{Mg}$, and $\mathrm{Al}$ were extracted with neutral 1 mol $\mathrm{L}^{-1} \mathrm{KCl}$ in a 1:10 soil:solution ratio and determined by
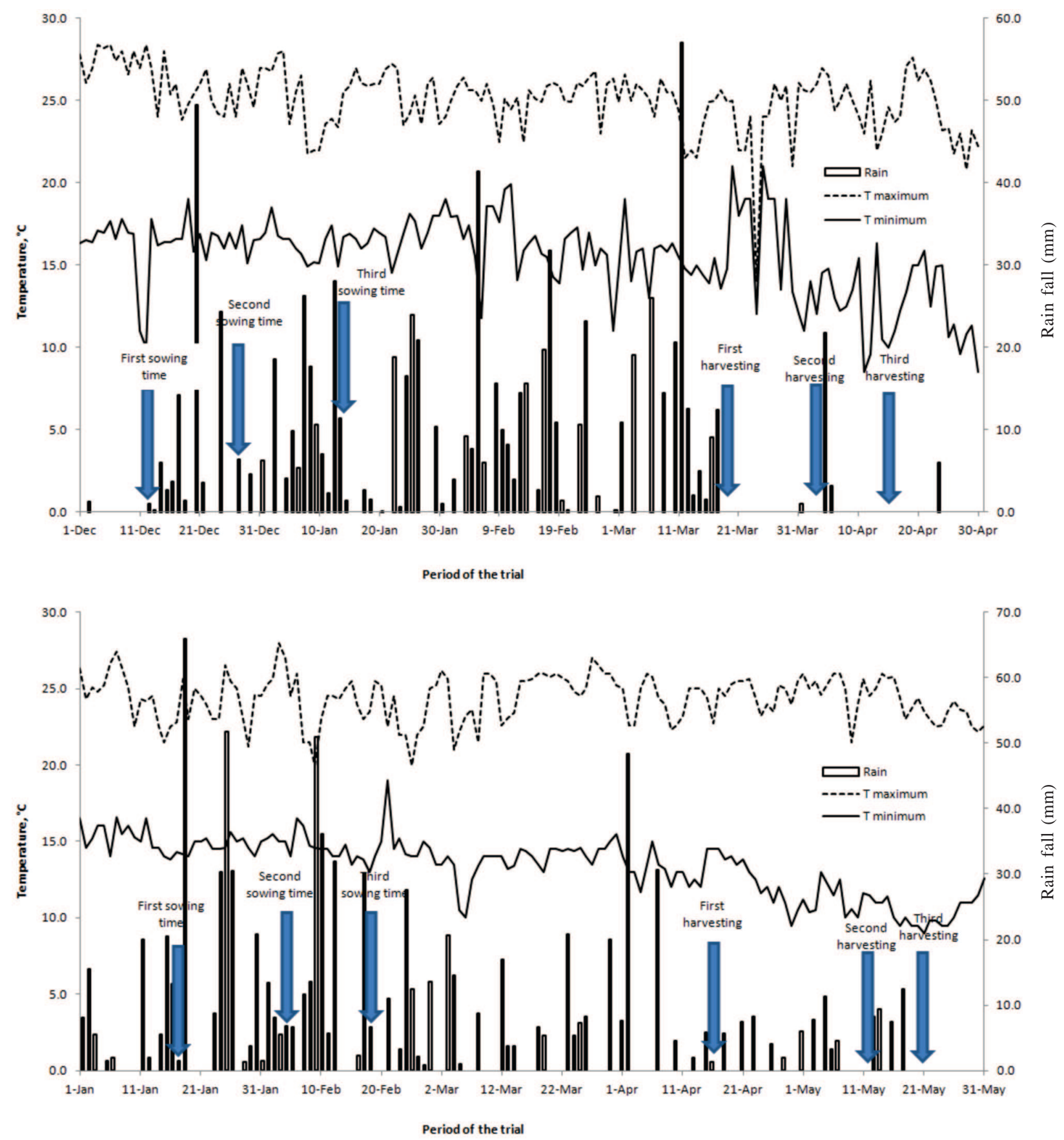

Figure 1: Rain fall and maximum and minimum temperatures of the experimental area during common bean cultivation in the growing seasons 2012/2013 and 2013/2014. 
titration with a $0.025 \mathrm{~mol} \mathrm{~L}^{-1} \mathrm{NaOH}$ solution. Phosphorus and exchangeable $\mathrm{K}$ were extracted with a Mehlich 1 extracting solution $\left(0.05 \mathrm{M} \mathrm{HCl}\right.$ in $\left.0.0125 \mathrm{M} \mathrm{H}_{2} \mathrm{SO}_{4}\right)$. The extracts were calorimetrically analyzed for $\mathrm{P}$ and flame photometry was used to analyze K. The base saturation values were calculated using the results of exchangeable bases and total acidity at $\mathrm{pH} 7.0(\mathrm{H}+\mathrm{Al})$. Soil organic matter was determined by the method of Walkley and Black.

The experimental design was a randomized block design in a $5 \times 3 \times 2$ factorial arrangement, with four replications. Treatments were the combination of five common bean cultivars (BRS Pontal, BRS Agreste, BRS Perola, and BRS Requinte from Brazil, and Encarnada, from Mozambique as a control) with three sowing times (beginning of the raining season, and 15, and 30 days after) with two growing seasons. Each plot consisted of six rows of $6 \mathrm{~m}$ long, with a useful area of three central rows, disregarding $0.5 \mathrm{~m}$ from the ends of each row. A range of 1 $\mathrm{m}$ between plots was used.

Conventional soil tillage (one plowing and two disking procedures) was conducted. The sowing of the common bean was manually held on December $12^{\text {th }}$ and December $29^{\text {th }}, 2012$, and January $1^{\text {st }}, 2013$, in the first growing season and January $19^{\text {th }}$, February $5^{\text {th }}, 2014$, and February $18^{\text {th }}, 2014$, in the second growing season. A row spacing of $0.45 \mathrm{~m}$ and density of eight seeds $\mathrm{m}^{-1}$ were used. In the first growing season, seedling emergence occurred at four, five, and six days after sowing, respectively, for each sowing time. In the second growing season, seedling emergence occurred at six, five, and five days after sowing, respectively, for each sowing time. Sowing fertilization was done in all plots using $48 \mathrm{~kg} \mathrm{ha}^{-1}$ of $\mathrm{N}$ (urea), $96 \mathrm{~kg} \mathrm{ha}^{-1}$ of
$\mathrm{P}_{2} \mathrm{O}_{5}$ (triple superphosphate), and $88 \mathrm{~kg} \mathrm{ha}^{-1}$ of $\mathrm{K}_{2} \mathrm{O}$ (potassium chloride). A topdressing fertilization was performed at $\mathrm{V}_{4}$ vegetative stage of common bean (three trifoliate leaves) with $90 \mathrm{~kg} \mathrm{ha}^{-1}$ of $\mathrm{N}$ as urea, in all plots and in both growing seasons. Weed control was done manually and no control of diseases and insects was conducted.

In the first growing season, harvesting was conducted on March 20 ${ }^{\text {th }}$, April $3^{\text {rd }}$, and April $13^{\text {th }}, 2013$, respectively, for each sowing time. In the second growing season, harvesting was conducted on April $17^{\text {th }}$, May $12^{\text {th }}$, and May $21^{\text {st }}, 2014$, respectively, for each sowing time. The plots was harvested manually, followed by mechanized thresher. The harvested common bean grains were weighed and the yield expressed as $\mathrm{kg} \mathrm{ha}^{-1}$. In addition, the following yield components were assessed: number of pods per plant, number of grains per pod (evaluated in 10 plants per plot that were chosen at random), and weight of 100 grains (calculated from eight random samples per plot).

Data were subjected to analysis of variance and means were compared by Tukey test at $\mathrm{p}<0.05$. In these analyzes, the SAS statistical software (SAS, 1999) was used.

\section{RESULTS AND DISCUSSION}

There was single effect of sowing time in number of pods per plant, number of grains per pods and mass of 100 grains (Table 2). There was interaction of cultivars and growing season for number of pods per plant, number of grain per pods, and mass of 100 grains. In grain yield, there was triple interaction among cultivars, sowing time, and growing season.

Table 1: Soil properties results of the experimental area of Lichinga county, province of Niassa, Mozambique in the growing seasons 2012/13 and 2013/14

\begin{tabular}{|c|c|c|c|c|c|c|}
\hline \multirow{3}{*}{ Layer } & \multicolumn{6}{|c|}{ Growing season 2012/13 } \\
\hline & \multirow{2}{*}{$\begin{array}{c}\text { pH } \\
\text { in water }\end{array}$} & $\mathbf{P}$ & $\mathbf{K}^{+}$ & $\mathbf{A l}^{+3}$ & $\mathrm{Ca}^{+2}$ & $\mathrm{Mg}^{+2}$ \\
\hline & & \multicolumn{2}{|c|}{$\mathrm{mg} \mathrm{kg}^{-1}$} & \multicolumn{3}{|c|}{$\operatorname{mmol}_{c} \mathbf{k g}^{-1}$} \\
\hline $0-0.20 \mathrm{~m}$ & 6.1 & 24 & 116 & 6.5 & 11.5 & 4.5 \\
\hline \multirow{2}{*}{ Layer } & $\mathbf{H}+\mathbf{A l}$ & CEC & $\mathrm{CEC}_{\mathrm{e}}$ & BS & SOM & Clay \\
\hline & \multicolumn{4}{|c|}{$\mathrm{mmol}_{\mathrm{c}} \mathrm{kg}^{-1}$} & \multicolumn{2}{|c|}{$\mathrm{g} \mathrm{kg}^{-1}$} \\
\hline \multirow[t]{2}{*}{$0-0.20 \mathrm{~m}$} & 54.9 & 73.8 & 25.5 & 19.0 & 24 & 440 \\
\hline & \multicolumn{6}{|c|}{ Growing season 2013/14 } \\
\hline \multirow[t]{2}{*}{ Layer } & pH & $\mathbf{P}$ & $\mathbf{K}^{+}$ & $\mathbf{A l}^{+3}$ & $\mathrm{Ca}^{+2}$ & $\mathbf{M g}^{+2}$ \\
\hline & in water & \multicolumn{2}{|c|}{$\mathrm{mg} \mathrm{kg}^{-1}$} & \multicolumn{3}{|c|}{$\mathbf{m m o l}_{\mathrm{c}} \mathbf{k g}^{-1}$} \\
\hline $0-0.20 \mathrm{~m}$ & 6.3 & 23 & 115 & 6.7 & 11.0 & 4.4 \\
\hline \multirow{2}{*}{ Layer } & $\mathbf{H}+\mathbf{A l}$ & CEC & $\mathrm{CEC}_{\mathrm{e}}$ & BS & SOM & Clay \\
\hline & \multicolumn{4}{|c|}{$\mathrm{mmol}_{\mathrm{c}} \mathrm{kg}^{-1}$} & \multicolumn{2}{|c|}{$\mathrm{g} \mathrm{kg}^{-1}$} \\
\hline $0-0.20 \mathrm{~m}$ & 55.1 & 72.7 & 23.4 & 18.0 & 23 & 440 \\
\hline
\end{tabular}

CEC - cation exchange capacity; BS - base saturation; SOM - soil organic matter. 
In the interaction cultivar $\times$ growing season, cultivars BRS Pontal and BRS Requinte had similar values in both growing seasons (Table 3). Perola and BRS Agreste had higher number of pods per plant in the growing season 2012/2013 than in 2013/2014. Cultivar Encarnada, from Mozambique, had higher values in the growing season 2013/2014 than in 2012/2013. In the growing season 2012/ 2013, the cultivar Encarnada had the lowest number of pods per plant and differed from all the other cultivars. In the growing season 2013/2014, cultivars Encarnada and Perola had the lowest values and differed from the other cultivars. By the results, it may be inferred that BRS Pontal and BRS Requinte are the most stable cultivars for this characteristic, once they presented similar values in both years.

In interaction cultivar $\times$ growing season for the variable number of grains per pod, it was observed that BRS Pontal, BRS Requinte, Perola, and BRS Agreste had similar values in both growing seasons (Table 4). On the other hand, Encarnada had the highest values in the growing season 2013/2014. In the first growing season, Encarnda had the lowest number of grain per pods and differed from all the other cultivars. In the second growing season, Encarna also had the lowest values and differed from Perola. All Brazilian cultivars were very stable in this characteristic. The number of grains per pods is a peculiar characteristic of each cultivar, genetically determined, with little influence of the environment (Pelá et al., 2009; Nascente et al., 2014). Encarnada is a local cultivar from Mozambique and it likely has some level of genetic differences and because of this showed difference in both years for this characteristic.

Perola, BRS Agreste, and Encarnada had similar values for the variable mass of 100 grains (Table 5). BRS Pontal and BRS Requinte had higher mass of 100 grain in the growing season 2013/2014 than in 2012/2013. In the growing season 2012/2013, Encarnada had the highest value and differed from BRS Pontal, BRS Requinte, and BRS Agreste. In the growing season 2013/2014, BRS Pontal had the

Table 3: Interaction Cultivar $\times$ growing season for the variable number of pods per plant of common bean

\begin{tabular}{llcc}
\hline Factor & & $\mathbf{2 0 1 2 / 2 0 1 3}$ & $\mathbf{2 0 1 3 / 2 0 1 4}$ \\
\cline { 1 - 1 } \cline { 4 - 4 } Cultivar & & Pods per plants (number) \\
\hline BRS Pontal & & $17.67 \mathrm{aA}$ & $17.17 \mathrm{aA}$ \\
BRS Requinte & & $19.33 \mathrm{aA}$ & $17.58 \mathrm{aA}$ \\
Pérola & & $18.53 \mathrm{aA}$ & $11.00 \mathrm{bB}$ \\
BRS Agreste & & $21.67 \mathrm{aA}$ & $15.67 \mathrm{aB}$ \\
Encarnada & & $8.75 \mathrm{bB}$ & $11.92 \mathrm{bA}$ \\
\hline
\end{tabular}

Means followed by the same uppercase letter in rows and lowercase in columns do not differ by Tukey test at $\mathrm{p} \geq 0.05$.

Table 2: Number of pods per plant (NPP), number of grains per pods (NGP), mass of 100 grains (M100), and grain yield (YIELD) of common bean as function of cultivars and sowing time

\begin{tabular}{|c|c|c|c|c|}
\hline $\begin{array}{l}\text { Factor } \\
\text { Cultivar }\end{array}$ & $\begin{array}{c}\text { NPP } \\
\text { number }\end{array}$ & $\begin{array}{c}\text { NGP } \\
\text { number }\end{array}$ & $\begin{array}{c}\text { M100 } \\
\mathrm{g}\end{array}$ & $\begin{array}{l}\text { YIELD } \\
\text { kg ha }^{-1}\end{array}$ \\
\hline BRS Pontal & 17.42 & 6.51 & 25.70 & 2032 \\
\hline BRS Requinte & 18.46 & 6.54 & 24.15 & 1955 \\
\hline Pérola & 14.76 & 6.33 & 24.89 & 1956 \\
\hline BRS Agreste & 18.67 & 6.25 & 24.85 & 2337 \\
\hline Encarnada & 10.65 & 5.13 & 26.66 & 1168 \\
\hline \multicolumn{5}{|l|}{ Sowing time } \\
\hline First sowing time & $15.15 \mathrm{~b}$ & $6.21 \mathrm{a}$ & $25.27 \mathrm{ab}$ & 1914 \\
\hline Second sowing time & $18.60 \mathrm{a}$ & $6.38 \mathrm{a}$ & $25.92 \mathrm{a}$ & 2076 \\
\hline Third sowing time & $14.68 \mathrm{~b}$ & $5.98 \mathrm{a}$ & $24.43 \mathrm{~b}$ & 1752 \\
\hline \multicolumn{5}{|l|}{ Growing season } \\
\hline $2012 / 2013$ & 14.67 & 6.13 & 24.77 & 1764 \\
\hline $2013 / 2014$ & 17.79 & 6.25 & 25.60 & 2055 \\
\hline Factor & \multicolumn{4}{|c|}{ ANOVA (F probability) } \\
\hline Cultivars $(\mathrm{C})$ & $<0.001$ & $<0.001$ & 0.0081 & $<0.001$ \\
\hline Sowing timing (ST) & $<0.001$ & 0.0304 & 0.0062 & 0.0012 \\
\hline $\mathrm{C} \times \mathrm{ST}$ & 0.1359 & 0.4683 & 0.0609 & 0.1003 \\
\hline Growing season (GS) & $<0.001$ & 0.1023 & 0.1738 & $<0.001$ \\
\hline $\mathrm{C} \times \mathrm{GS}$ & $<0.001$ & 0.0003 & 0.0001 & 0.0536 \\
\hline $\mathrm{ST} \times \mathrm{GS}$ & 0.6090 & 0.2962 & 0.0519 & 0.0051 \\
\hline $\mathrm{C} \times \mathrm{GS} \times \mathrm{ST}$ & 0.7053 & 0.3244 & 0.2656 & 0.0008 \\
\hline $\mathrm{CV}(\%)$ & 20.18 & 12.49 & 8.68 & 21.39 \\
\hline
\end{tabular}

$\mathrm{CV}$ - coefficient of variation.

Means followed by the same lowercase letter in columns do not differ by Tukey test at $\mathrm{p} \geq 0.05$.

Rev. Ceres, Viçosa, v. 64, n.5, p. 532-539, set/out, 2017 
highest value and differed from Perola. Mass of 100 grains is more influenced by environmental conditions (Araújo et al., 1996) and because of this, we observed more differences among cultivars.

Regarding grain yield, a triple interaction occurred among growing season, cultivars, and sowing time (Table 6). In the growing season 2012/2013, all the cultivars had

Table 4: Interaction Cultivar $\times$ growing season for the variable number of grains per pods of common bean

\begin{tabular}{llcc}
\hline Factor & & $\mathbf{2 0 1 2 / 2 0 1 3}$ & $\mathbf{2 0 1 3 / 2 0 1 4}$ \\
\cline { 1 - 1 } \cline { 4 - 4 } Cultivar & & Grains per pods & (number) \\
\hline BRS Pontal & & $6.67 \mathrm{aA}$ & $6.36 \mathrm{abA}$ \\
BRS Requinte & & $6.75 \mathrm{aA}$ & $6.33 \mathrm{abA}$ \\
Pérola & & $6.17 \mathrm{aA}$ & $6.50 \mathrm{aA}$ \\
BRS Agreste & & $6.25 \mathrm{aA}$ & $6.25 \mathrm{abA}$ \\
Encarnada & & $4.13 \mathrm{bB}$ & $5.81 \mathrm{bA}$ \\
\hline
\end{tabular}

Means followed by the same uppercase letter in rows and lowercase in columns do not differ by Tukey test at $\mathrm{p} \geq 0.05$.

Table 5: Interaction Cultivar $\times$ growing season for the variable mass of 100 grains of common bean

\begin{tabular}{|c|c|c|}
\hline Factor & $2012 / 2013$ & $2013 / 2014$ \\
\hline Cultivar & \multicolumn{2}{|c|}{ Mass of 100 grains (grams) } \\
\hline BRS Pontal & $24.39 \mathrm{bB}$ & $27.00 \mathrm{aA}$ \\
\hline BRS Requinte & $22.92 \mathrm{bB}$ & $25.39 \mathrm{abA}$ \\
\hline Pérola & $25.52 \mathrm{abA}$ & $24.25 \mathrm{bA}$ \\
\hline BRS Agreste & $24.04 \mathrm{bA}$ & $25.67 \mathrm{abA}$ \\
\hline Encarnada & $28.11 \mathrm{aA}$ & $25.69 \mathrm{abA}$ \\
\hline
\end{tabular}

Means followed by the same uppercase letter in rows and lowercase in columns do not differ by Tukey test at $\mathrm{p} \geq 0.05$. higher values in the second sowing time (December $29^{\text {th }}$, 2012). BRS Requinte yielded more also in the second sowing time (December 12 $\left.{ }^{\text {th }}, 2012\right)$. Encarnada and Perola had better results in the third sowing time (January $13^{\text {th }}, 2013$ ). In the second growing season, for BRS Agreste, Pontal, and Encarnada, better results were achieved in the first sowing time (January 19 $\left.{ }^{\text {th }}, 2014\right)$. Perola and Encarnada yielded more in the second sowing time (February $5^{\text {th }}, 2014$ ) and BRS Pontal and BRS Requinte had higher grain yield in the third sowing time (February $18^{\text {th }}, 2014$ ).

The differences in the grain yield of common bean cultivars could be due to better adaptation of each material for the environmental conditions. The rainfall was in the range that provides high grain yield for the common bean. In the growing season 2012/2013, the rainfall was 790.0, 678.3, and $563.2 \mathrm{~mm}$ for the first, second, and third sowing time, respectively (Figure 1). In the second growing season, the rainfall was 697.4, 569.5, and 418.2 $\mathrm{mm}$ for the first, second, and third sowing time, respectively. According to Cunha et al. (2013) and Fancelli \& Dourado Neto (2007), common bean requires at least $300 \mathrm{~mm}$ of well distributed rainfall during the crop cycle and in the critical periods during the flowering and the initial stage of pod formation (Cunha et al., 2013). In this sense, we could observe that in all sowing time, the amount of rain was higher than $300 \mathrm{~mm}$; however, it is important to note that when sowing time is delayed, the amount of rain reduced (from 790 to $563 \mathrm{~mm}$ in 2012/2013 and from 697 to $418 \mathrm{~mm}$ in 2013/2014). Therefore, it is safer for the farmers to start the sowing of common bean in the beginning of the growing season.

Table 6: Interaction Cultivar $\times$ sowing time $\times$ growing season for the variable grain yield of common bean

\begin{tabular}{|c|c|c|c|}
\hline \multicolumn{4}{|c|}{ Growing season 2012/2013 } \\
\hline \multirow{3}{*}{ Cultivar } & \multicolumn{3}{|c|}{ Sowing time } \\
\hline & December $12^{\text {th }}, 2012$ & December $29^{\text {th }}, 2012$ & January $13^{\text {th }}, 2013$ \\
\hline & \multicolumn{3}{|c|}{ kg ha-1 } \\
\hline BRS Agreste & $2127 \mathrm{aB}^{*}$ & $2850 \mathrm{aA}$ & $2183 \mathrm{aB}$ \\
\hline Pérola & $1330 \mathrm{bB}$ & $2287 \mathrm{aA}$ & $1699 \mathrm{abAB}$ \\
\hline BRS Pontal & $1509 \mathrm{abB}$ & $2271 \mathrm{aA}$ & $1485 \mathrm{abB}$ \\
\hline BRS Requinte & $1882 \mathrm{abA}$ & $2209 \mathrm{aA}$ & $1149 \mathrm{bcB}$ \\
\hline Encarnada & - & $783 \mathrm{bA}$ & $927 \mathrm{cA}$ \\
\hline \multicolumn{4}{|c|}{ Growing season $2013 / 2014$} \\
\hline \multirow[t]{3}{*}{ Cultivar } & \multicolumn{3}{|c|}{ Sowing time } \\
\hline & January $19^{\text {th }}, 2014$ & February $5^{\text {th }}, 2014$ & February $18^{\text {th }}, 2014$ \\
\hline & \multicolumn{3}{|c|}{$\mathrm{kg} \mathrm{ha}^{-1}$} \\
\hline BRS Agreste & $2615 \mathrm{aA}$ & $2035 \mathrm{bC}$ & $2214 \mathrm{aB}$ \\
\hline Pérola & $1780 \mathrm{abB}$ & $2693 \mathrm{aA}$ & $1948 \mathrm{aB}$ \\
\hline BRS Pontal & $2313 \mathrm{aA}$ & $2184 \mathrm{abB}$ & $2431 \mathrm{aA}$ \\
\hline BRS Requinte & $2160 \mathrm{aB}$ & $1841 \mathrm{bC}$ & $2490 \mathrm{aA}$ \\
\hline Encarnada & $1515 \mathrm{bA}$ & $1610 \mathrm{cA}$ & $1002 \mathrm{bB}$ \\
\hline
\end{tabular}

Means followed by the same uppercase letter in rows and lowercase in columns do not differ by Tukey test at $\mathrm{p} \geq 0.05$. 
The minimum and maximum temperatures during the crop development were very close to the required by the common bean plants (Figure 1). In the first growing season, minimum and maximum temperatures were 16.2 and $25.2,16.1$ and 24.9 , and 15.8 and $24.9^{\circ} \mathrm{C}$ in the first, second, and third sowing time, respectively. In the growing season 2013/2014, minimum and maximum temperatures were 14.1 and $24.3,13.4$ and 24.4 , and 12.5 and $24.5^{\circ} \mathrm{C}$ in the first, second, and third sowing time, respectively. According to Gonçalves et al. (1997), Maluf et al. (2001), and Fancelli \& Dourado Neto (2007), the best range of temperature for common bean development is between 15 and $29.5^{\circ} \mathrm{C}$. On the other hand, high air temperatures $\left(>35^{\circ} \mathrm{C}\right.$ ) are harmful to the production of beans, especially during critical phases such as flowering (R6), pod formation (R7), and grain filling (R8) (Araújo et al., 1996). In this sense, we could observe that in Lichinga, there were no temperatures above $35^{\circ} \mathrm{C}$. However, the sowing time should be earlier, close to the beginning of the raining season, because if the time of sowing is delayed, it could coincide with the lower temperature that varied from $16.2,16.1$, and $15.8^{\circ} \mathrm{C}$ in the first, second, and third sowing time, respectively, in the first growing season and $14.1,13.4$, and $12.5^{\circ} \mathrm{C}$ in the first, second, and third sowing time, respectively, at the second growing season. Temperatures below $15{ }^{\circ} \mathrm{C}$ could provide reduction in common bean grain yield (Fancelli \& Dourado Neto, 2007). As a conclusion, we can infer that the climate conditions of Lichinga in Mozambique are suitable for common bean development. However, better results could be achieved if the sowing time was done in the beginning of the raining season to avoid problems with low rainfall and temperature.

Among cultivars, BRS Pontal stood out and had the highest grain yield in all sowing times and in both growing seasons. BRS Agreste also had the highest grain yield in all sowing times and in both growing seasons, except in the growing season 2013/2014 in the second sowing time (Table 6). Cultivar Encarnada, from Mozambique, had the lowest grain yield in all sowing times evaluated. Despite the differences among cultivars, the grain yields achieved were satisfactory, with values higher than the average of Mozambique, which is $345 \mathrm{~kg} \mathrm{ha}^{-1}$ (FAOSTAT, 2015). Based on the results, it can be inferred that the use of technologies such as the use of seed of Brazilian cultivars, especially BRS Agreste and BRS Pontal, proper sowing time, sowing and topdressing fertilization, and control of weeds were effective to significantly increase the productivity of common bean crop grain in Mozambique, Africa. These data are very important and show opportunities to expand food production and a good source of protein in places where there are serious problems of malnutrition and hunger (CGIAR, 2015).

\section{CONCLUSIONS}

BRS Pontal was the most productive in all sowing times.

The cultivar Encarnada was the less productive cultivar in all sowing times and growing seasons.

The best sowing time was in the beginning of the raining season.

The use of technologies allows significant increase of grain yield in Lichinga, Mozambique.

\section{REFERENCES}

Araújo RS, Rava CA, Stone LF \& Zimmermann MJ de O (1996) Cultura do feijoeiro comum no Brasil. Piracicaba, Associação Brasileira para Pesquisa de Potassa e do Fosfato. 786p.

Birthal PS, Parthasarathy Rao P, Nigam SN, Bantilan MCS \& Bhagavatula S (2010) Groundnut and Soybean Economies in Asia: Facts, Trends and Outlook. Andhra Pradesh, International Crops Research Institute for the Semi Arid Tropics. 92p.

CGIAR (2011) Grain legume value alliance. Available at: <http:// cgiarweb.s3.amazonaws.com/wp-content/uploads/2011/08/ CRP3.5-GLVA-03May2011.pdf>. Acessed on: October 29 2015.

CGIAR (2015) Common bean. Available at: <http://www.cgiar.org/ our-strategy/crop-factsheets/beans/>. Acessed on: October $10^{\text {th }}$, 2015.

Claessen MEC (1997) Manual for Methods of Soil Analysis. $2^{\text {nd }}$ ed. Rio de Janeiro, Embrapa Solos. 212 p.

Cunha PCR, Silveira PM, Nascimento JL \& Alves Júnior J (2013) Manejo da irrigação no feijoeiro em plantio direto. Revista Brasileira de Engenharia Agrícola e Ambiental, 17:735-742.

Dalla Corte A, Moda-Cirino V \& Destro D (2002) Adaptability and phenotypic stability in early common bean cultivars and lines. Crop Breeding and Applied Biotechnology, 2:525-534.

Fageria NK (2002) Nutrient management for sustainable dry bean production in the tropics. Communication in Soil Science and Plant Analysis, 33:1537-1575.

Fancelli AL \& Dourado Neto D (2007) Produção de feijão. Piracicaba, Agropecuária. 386p.

FAO (1998) World Reference base for soil resource FAO. Available at: 〈http://www.fao.org/docrep/w8594e/w8594e00.HTM>. Accessed on: November $2^{\text {nd }}, 2015$.

FAOSTAT (2015) Production: Crops. Available at: <www.faostat.fao.org>. Accessed on: September 29 2015.

Gonçalves SL, Wrege MS, Caramori PH, Mariot EJ \& Abucarub Neto M (1997) Probabilidade de ocorrência de temperaturas superiores a $30{ }^{\circ} \mathrm{C}$ no florescimento do feijoeiro (Phaseolus vulgaris 1.) cultivado na safra das águas no estado do Paraná. Revista Brasileira de Agrometeorologia, 5:99-107.

Kumar P, Joshi PK \& Birthal OS (2009) Demand projections for food grains in India. Agricultural Economics Research Review, 22:237-243.

Maluf JRT, Cunha GR, Matzenauer R, Pasinato A, Pimentel MBM \& Caiaffo MR (2001) Zoneamento climático para a cultura do feijão no Rio Grande do Sul. Revista Brasileira de Agrometeorologia, 9:468-476.

Mbanze AA, Batista AC, Tetto AF, Koehler HS \& Manteiga JB (2015) Influence of the meteorological conditions on forest fires occurrences in Lichinga district, northern Mozambique. Revista Floresta, 45:577-586. 
MAE - Ministério da Administração Estatal (2005) República de Moçambique. Perfil do distrito de Lichinga. Província de Niassa, MAE. 54 p.

Nascente AS \& Cobucci T (2015) Soil phosphorus availability and dry bean yield as affected by the application of liquid calcium carbonate micron particles on the furrow. African Journal of Agricultural Research, 10:1840-1851.

Nascente AS, Cobucci T, Sousa DMG \& Lima DP (2014) Adubação fosfatada no sulco e foliar afetando a produtividade de grãos do feijoeiro comum. Semina: Ciências Agrárias, 35:1231:2014.

Nascente AS, Kluthcouski J, Crusciol CAC, Cobucci T \& Oliveira P (2012) Adubação de cultivares de feijoeiro comum em várzeas tropicais. Pesquisa Agropecuária Tropical, 42:407-415.

Parthasarathy Rao P, Birthal P, Bhagavatula S \& Bantilan M (2010) Chickpea and Pigeonpea Economies in Asia: Facts, Trends and Outlook. Patancheru, ICRISAT. 68 p.
Pelá A, Rodrigues Ms, Santana JS \& Teixeira Ir (2009) Fontes de fósforo para a adubação foliar na cultura do feijoeiro. Scientia Agraria, 10:313-318.

Redden RJ, Delacy IH, Butler DG \& Usher T (2000) Analysis of line $\mathrm{x}$ environment interactions for yield in navy beans. 2 . Pattern analysis of lines and environment within years. Australian Journal of Agricultural Research, 51:607-617.

SAS Institute Inc. (1999) Procedure guide for personal computers. Version 5. Cary, Statistical Analysis System Institute. 51p.

Shinano T, Osaki M, Komatsu K \& Tadano T (1993) Comparison of production efficiency of the harvesting organs among field crops. I. Growth efficiency of the harvesting organs. Soil Science Plant Nutrition, 39:269-280. 